\title{
Analysis of Factors Affecting: Sales Volume of Small and Medium Enterprises (SMEs) in Surabaya
}

\author{
Martha Suhardiyah ${ }^{1}$, Subakir $^{1} \&$ Sulistyowati ${ }^{2}$ \\ ${ }^{1}$ The Program of Study of Accounting, Economics Faculty PGRI Adi Buana University of Surabaya, Indonesia \\ ${ }^{2}$ Biology Study Program, the Faculty of MIPA, University of PGRI Adi Buana Surabaya, Indonesia \\ Correspondence: Priyono, Post Graduate Management Program, University Bina Darma Palembang, Indonesia. \\ Tel: 62-812-1697-4878. E-mail: priyono.unu_sidoarjo@yahoo.com
}

Received: February 17, 2016

Accepted: March 9, 2016

Online Published: April 25, 2016

doi:10.5539/ijef.v8n5p63

URL: http://dx.doi.org/10.5539/ijef.v8n5p63

\begin{abstract}
The purpose of this study is to investigate and examine the factors that affect the sales volume SMEs, respondent 101 SMEs obtained that variable Venture Capital (X1) Number of Workers (X2), Hours of Work (X3), Experience (X4) of the Sales Volume (Y), simultaneously influence while variable Production technology and Innovation (X5) and Strategic Marketing (X6) of the Sales Volume (Y) partially has dominant influence.

The research instrument used questionnaire, were analyzed using multiple linear regression analysis. The unit of analysis of this research is the management of SMEs Surabaya, who became the target Cooperatives and SME Surabaya in 2013 as many as 315 SMEs engaged in some business sectors such as the following: Handicraft (39), Sewing (16), Handicraft Water Hyacinth (38), ribbon embroidery (44), Processed fish (29), Pastry (50), Wet Cake (50) Beverages (26), crackers (37). In this study took a sample of 101 respondents from various fields of business data analysis contained significant effect on the dependent variable, and the result is expected to be used as one of the considerations in making decisions in developing SMEs.
\end{abstract}

Keywords: factors of sales volume, SMEs

\section{Introduction}

National small and micro enterprises in indonesia amounted to about 52.1 million to contribute in gross domestic product ( GDP ) by $33 \%$ and created employment 91.03\%. (Grisna Anggadwita \& Qaanita Yuuha Mustafid, 2013) Rather large businesses which amounted to only 4,677 or $0.01 \%$ of total company and absorb employee only $2.70 \%$ of GDP would be able to contribute quite high, at $43.47 \%$. Contributions to non-oil exports of the highest large enterprises, namely 82.96. Medium-sized business sector of its business units as many as 41133 units. Contribution to employment, ie, $21.7 \%$ and $13.47 \%$ of GDP. Small businesses as much as 546567 units or $1.04 \%$. whereas on employment of $3.56 \%, 9.96 \%$ of GDP and $3.87 \%$ of non-oil exports. (Choirul Anam, 2012). Based on these data, it can be said that SMEs make a major contribution in contributing to the country's economic growth ( Nunuy Nur Afiah, 2009).

Data Department of Cooperatives and SMEs in Surabaya, there are resources that SMEs of potential for development of SMEs in 2010 there were 977; In 2011 there were 547 SMEs and in 2012 there were 489 SMEs from these data the number of SMEs has decreased because it is necessary to prevent their troubled SMEs causing some SMEs experience liquidation/folded. Surabaya government through the Department of Cooperatives and SMEs have to provide guidance on business/small industry sector in order to survive and expanded so can help the growth of the economy and address the employment issues but these efforts have not fully succeeded in developing SMEs.

Several studies from other countries, economic development in a country (Mazzarol, Volery, Doss, \& Thein, 1999). One of the important role of SMEs in this context include poverty alleviation through employment creation. SMEs in some other countries such as Thailand are increasingly seen as a creator of new jobs (Swierczek \& Ha, 2003) and SME Vietnam has hired 64\% of the industrial workforce, Thailand statistical data provided by the NSO (2007), said SMEs accounted for $76.1 \%$ percent of all companies in the manufacturing sector in 2007. the largest concentration, with the number of SMEs in Thailand are in the sectors of food and beverages, textiles, wearing apparel, and wood and wood products (NSO, 2007). 
Most studies ignore gender as a variable attention or excluded female subjects of their design. It is usually that men and women have a performance impact on the company, as this effect has been understood, factors that affect the presentation of gender that has not been fully clarified (Brush \& Hirsch, 2000) although gender has an impact in the middle of the operator small-scale enterprises in the sector companies scale little understood as an integral constituent of the commercial progress and important agent in his power to lift the country out of poverty (Wolfensohn, 2001). The small scale companies have the power to commercial development, conception of work, and poverty reduction in developing countries. They have roads in that commercial development acceleration and rapid development has been achieved (Francis, 2000). Besides small-scale enterprises has been understood as the ability of the feeder for large-scale industry (Wolfensohn, 2001).

\subsection{Research Problems}

1 ) Is the business capital, the amount of labor, business experience, technology and production innovation and marketing strategy, simultaneously affecting an increasing volume of sales of SMEs in Surabaya?

2 ) Among the factors working capital, the amount of labor, business experience, technology and production innovation and marketing strategy where the dominant influence on the increase of sales volume of SMEs in Surabaya?

\section{Literature Review}

(Bridge, O'Neill, \& Cromie 2003; Salminen, 2000) describe a company as a controlled system consists of detectors, voters and effectors. the detector is a function of where the system to obtain information about its environment, which is then used as the basis for the selection of behavioral responses by voters. Finally, run by the behavior of effectors. The measurement system of a company collects information about the changes in both the environment and the company's performance. This information is then used together with the values and preferences of the company and management to make decisions about actions needed. The output of the company - product, service, operational and financial performance Performance - changed.

One of the main problems that arise when dealing with SMEs is the lack of clear and universally accepted definition. Attempts to define SMEs have led to a tremendous diversity of conception actually generated debate about different approaches to define SMEs. Companies differ in their level of capitalization, sales, and employment. Varieties definitions have been applied between different countries and different criteria have to be considered to determine them. But generally, SMEs are considered non-independent subsidiaries employing less than the amount provided by the employee though this varies in each country. For example, in Scotland, a company Micro unbiased 0-9 employees (including sole traders) and 10-49 Small employees. mostly small companies are considered companies with less than 50 employees while micro-enterprises have at most ten, or in some cases, five employees (Malhotra, Chen, Criscuolo, Fan, Hamel, \& Savchenko, 2006). In defining SMEs, in addition to considering the number of employees involved in the business, financial aspects such as turnover and total assets or total balance sheet is also taken into account.

(Joseph F. Engelberger, ....) said that innovation requires only three things:

1. unknown needs, 2. The competent persons with relevant technology, finance and 3. Support. Innovation by businesses is achieved in many ways, with a lot of attention now given to formal research and development for "breakthrough innovations". But innovation can be developed by less formal modification of on-the-job practice, through exchange and combination of professional experience and with many other routes. Innovation is more radical and revolutionary tend to emerge from $R \& D$, while more additional innovations may emerge from practice - but there are many exceptions to each of these trends

A recent study based survey of the factors that influence the success of SMEs. (Nurul Indarti \& Marja Langenberg, 2005) have identified a key component to be important in analyzing the success of the SME business which includes the characteristics of the entrepreneur; the characteristics of SMEs; and contextual elements of SME development. (Westhead, 1995) studied the factors that influence the survival of 227 high-tech small companies. (Ghosh \& Kwan, 1996) conducted a cross-national study of the cross key success factors of 152 SMEs in Singapore and 164 SMEs in Australia. (Kauranen, 1996) conducted a follow-up study of 37 new manufacturing company in Finland and studied the determinants of the future success of the company in the short term and in the long term. (Joseph, 1995) explored the critical success factors for small companies in several industry sectors based on employers' perceptions of 220 South Pacific. (Wijewardena \& Cooray, 1996) explored the importance of a series of factors of success by studying a sample of 300 small manufacturing companies in Japan. (Gadenne, 1998) examined the effects of various management practices on the performance of small company by studying 369 small businesses in the retail, service and manufacturing industries in Australia. (Bracker \& Pearson, 1986) 
studied planning and financial performance of mature small dry cleaning business. (Bracker et al., 1993) planning study in successful high-growth small companies. (Pelham, 2000) explores the relationship between market orientation and performance of manufacturing SMEs in eight industry sectors.

Based on the findings of previous studies, the factors that influence the success of the SME business is classified into the following categories: (1) an employer characteristics (Kristiansen, Furuholt, \& Wahid, 2003; Rutherford \& Oswald, 2000), (2) the characteristics of SMEs (Kristiansen, Furuholt, \& Wahid; 2003), (3) management and know- how (Swierczek \& Ha, 2003), (4) products and services (Wiklund, 1998; Hitt \& Ireland, 2000). (5) customer and market (William, James, \& Susan, 2005), (6) ways of doing business and cooperation (Hitt \& Ireland, 2000; and Jarillo, 1988). (7) and financial resources (Swierczek \& Ha, 2003; Kristiansen, Furuholt, \& Wahid, 2003). (8) the strategy (McMahon, 2001), (9) the external environment (Huggins, 2000; Nurul Indarti \& Marja Langenberg, 2005); and (10) internet (Henriette Hesselmann, Comcare, \& Peter Bangs; 2002). However, only six factors: Characteristics of SMEs, and knowledge management, Products and Services, the Way of Doing Business and Cooperation, Resources and Finance and External Environment considered for the theoretical framework of this research is based on compliance with the Malaysian context. Therefore, business success is dependent variable and the independent variables are: the characteristics of entrepreneurs and SMEs, management and know - how, products and services, ways of doing business and cooperation, and financial resources, and the outside environment.

Thus, the empirical investigation of the factors that led to the success and failure of a small business economy in different countries is a mandatory requirement for the development of better economic health. The findings were helpful and useful for individual entrepreneurs as well as economic development planner (Wijewardena \& Tibbits, 1999). Assuming that there tends to be a common underlying factors associated with success (Hills \& Narayana, 1990), many small business research has been conducted to identify the success factors in various countries. However, Luke (1996) states that the majority of previous studies based on the experience of a small company that operates both in North America or in the European countries. There has been a tremendous amount of research ranging from single case study for a comprehensive survey that explicitly investigate the success factors for small businesses (see, for example, Bird, 1989; Brockhaus \& Horwitz, 1982; Brockhaus \& Horwitz, 1986; Gartner, 1989; Sandberg, 1986; Vesper, 1990). Most of these studies concluded that business success is a result of the web interacting factors. However, the implementation and effectiveness of these factors in many countries is still open to investigation.

One of the main challenges in doing cross-country analysis of data of SMEs is the lack of a universal definition of what constitutes an SME. A number of efforts aimed to streamline and harmonize the definition of SMEs (OECD, 2004), despite the heterogeneity of SMEs themselves and the nature of the economies they operate in may mean that establishing a global definition is not feasible. We discuss the existing definition of SMEs below and explore the extent to which differences in definitions associated with the observed variation in the level of SME financing

\section{Research Methods}

\subsection{Research Design}

To obtain the results of the research in accordance with the goals set before the design of the study are presented in the figure below:

\begin{tabular}{|c|c|c|}
\hline Identification of variables and variable & Data analysis & superficial \\
\hline \multicolumn{3}{|l|}{ Independent Variable (X): } \\
\hline $\begin{array}{l}\text { 1. Venture capital consists of : } \\
\text { the amount of asset ownership, spacious building / construction, business location, } \\
\text { access to the outside }\end{array}$ & & \multirow{5}{*}{$\begin{array}{l}\text { Factors that } \\
\text { influence the salrs } \\
\text { volume SMEs }\end{array}$} \\
\hline $\begin{array}{l}\text { 2. The number of workers consists of : Number of labor, Job descriptions ; } \\
\text { Specifications jobs }\end{array}$ & & \\
\hline $\begin{array}{l}\text { 3. Working hours consist of : work schedule Business experience consisted of , the Old } \\
\text { business; business field }\end{array}$ & & \\
\hline $\begin{array}{l}\text { 4. Technology and innovation of production consists of : the model ,size, color, quality } \\
\text { products; product specification }\end{array}$ & & \\
\hline $\begin{array}{l}\text { 5. The marketing strategy consists of : Network marketing ; Promotional products } \\
\text { Professional organization, equipment / media promotion, distribution channels }\end{array}$ & & \\
\hline
\end{tabular}




\begin{tabular}{|l|l|l|}
\hline & \multicolumn{1}{|c|}{$\begin{array}{l}\text { Regression Analysis Model } \\
\text { Dependent Variable ( } \mathrm{Y} \text { ): }\end{array}$} \\
Sales volume SMEs in terms of : & \\
Total sales & \\
Sales value & $\mathrm{Y}+\mathrm{b}_{1} \mathrm{X}_{1}+\mathrm{b}_{2} \mathrm{X}_{2}+\mathrm{b}_{3} \mathrm{X}_{3}+\mathrm{b}_{4} \mathrm{X}_{4}+\mathrm{b}_{5} \mathrm{X}_{5}$ \\
\hline
\end{tabular}

Figure 1. Flow chart research

\subsection{Population and Sample}

The unit of analysis of this research is the management of SMEs Surabaya, who became the target Cooperatives and SME Surabaya in 2013 as many as 315 SMEs engaged in some business sectors such as the following: Handicraft (39), Sewing (16), Handicraft Water Hyacinth (38), Sulam Pita (44), Processed fish (29), Pastry (50), Wet Cake (50), Beverages (26), crackers (37). In this study took a sample of 101 respondents from various fields of business

\subsection{Research Variable}

The variables analyzed in this study grouped as follows

Exogenous or independent variable in this study is the business capital, number of employees, hours of work, business experience, technology and innovation as well as the production, marketing strategies yield Surabaya Endogenous or dependent variables are factors that predicted by a single or multiple constructs. Endogenous variable in this study is. The sales volume of SMEs

\subsection{Operational Definition of Variables}

The operational definition of each variable is presented in Table 2 below:

Table 2. The operational definition of each variable

\begin{tabular}{|c|c|c|}
\hline Variable & Variable name & Operational definition \\
\hline \multirow{3}{*}{ Dependent variables } & The sales volume ( Y 1 ) & - Total sales volume ( Y2.1 ) \\
\hline & & - Sales volume ( Y1.2 ) \\
\hline & Venture capital ( X1 ) & - The number of asset ownership ( X1.1), \\
\hline \multirow[t]{18}{*}{ independent variables } & & - Size of the building / buildings ( X1.2 ), \\
\hline & & - The business location (X1.3), \\
\hline & & - Access to the outside ( X1.4 ), \\
\hline & Number of Manpower (X2) & - The number of workers ( X2.1 ) \\
\hline & & • Job Description X2.2) \\
\hline & & - Job specifications ( X2.3 ) \\
\hline & Working hours ( X3 ) & - Work schedule ( X3.1) \\
\hline & & - The business sectors ( X3.2 ) \\
\hline & Business experience ( X4) & - Old business ( X 4.1 ) \\
\hline & Technology and innovation in & - the model , size , ( X5.1) \\
\hline & production ( X5 ) & $\cdot$ Color , ( X5.2 ) \\
\hline & & - the quality of the product ( X5.3 ) \\
\hline & & - specifications of the product ( X5.4 ) \\
\hline & Marketing strategy ( X6 ) & • Network marketing ( X 6.1 ) \\
\hline & & - Promotional products ( X 6.2 ) \\
\hline & & - Professional organizations ( X 6.3 ) \\
\hline & & • Tools / media promotion ( X 6.4 ) \\
\hline & & - distribution channels ( X 6.5 ) \\
\hline
\end{tabular}

\subsection{Data Analysis Techniques}

For the sake of discussion, the data is processed and presented based on statistical principles with analysis and hypothesis testing used inferential statistics using linear regression analysis with the formula:

$$
Y=b o+b_{1} X_{1}+b_{2} X_{2}+b_{3} X_{3}+b_{4} X_{4}+b_{5} X_{5}
$$

$\mathrm{Y}_{1}=$ The sales volume 
$\mathrm{X}_{1}=$ venture capital

$\mathrm{X}_{2}=$ total manpower

$\mathrm{X}_{3}$ = working hours

$\mathrm{X}_{4}=$ trying experience

$\mathrm{X}_{5}=$ technology and innovation in production

$\mathrm{X}_{6}=$ marketing strategy

\subsection{The Results Achieved}

Surabaya municipality is composed of 31 districts and 160 district. The data from the Department of Cooperatives and SMEs Surabaya city has 315 SMEs assisted consist of: Handicraft (39), Sewing (16), Handicraft Water Hyacinth (38), Sulam Pita (44), Processed fish (29), Pastries s (50), wet Cake (50) Beverages (26), crackers (37).

In this study took a sample of 101 respondents from various fields of business:

Table 3. Samples distribution

\begin{tabular}{clcclc}
\hline NO. & business fields & amount & NO. & business fields & amount \\
\hline 1 & Handycraft & 12 & 6 & cake & 17 \\
2 & ribbon embroidery & 9 & 7 & crackers & 8 \\
3 & processed fish & 21 & 8 & stitches shirt & 7 \\
4 & drink & 4 & 9 & Water hyacinth & 6 \\
5 & pastry & 17 & & & \\
& amount & & & 101 \\
\hline
\end{tabular}

Source: Department of Cooperatives and SMEs Surabaya (processed).

\subsection{Data Analysis and Discussion}

Based on data collection through questionnaires, the study aims to determine the effect of variable $\mathrm{Y}$ in the form of higher sales volume and variable $\mathrm{X}$ consisting of $\mathrm{X} 1=$ venture capital, $\mathrm{X} 2=$ the number of workers, $\mathrm{X} 3=$ hours of work, X4 = experience trying, X5 = technology and production innovation , and X6 = marketing strategies through multiple linear regression analysis with assistance program SPSS Statistics obtainable results as follows.

\subsection{Testing Instrument Research}

\subsubsection{Validity Test}

Test the validity of the questionnaire obtained by each score indicators correlate with the total score of the indicator variable, then the correlation results than the critical value at 0.05 significant level. If the analysis shows the significant value exceeding $0.05(>0.05)$, the items in the questionnaire did not show the validity of the value that it can not be continued as a research instrument .

Validity test is done using the product moment correlation, ( $\mathrm{r}$ count) compared with Pearson Correlation requirement if it is larger than the critical $\mathrm{r} 0.300$ matter the item is considered eligible for band is used as an instrument and vice versa (Nata Wirawan, 2002). From the analysis of the data obtained the following results:

Table 4. Validity

\begin{tabular}{cccc}
\hline No questionnaire & $\mathrm{r}$ amount & $\mathrm{t}$ requirement & information \\
\hline 1 & 1 & $>0,300$ & Item matter Valid \\
2 & $.356^{* *}$ & $>0,300$ & Item matter Valid \\
3 & $.687^{* *}$ & $>0,300$ & Item matter Valid \\
4 & 1,000 & $>0,300$ & Item matter Valid \\
5 & 1,000 & $>0,300$ & Item matter Valid \\
6 &, 133 & $>0,300$ & tem matter Valid \\
7 & $.534^{* *}$ & $>0,300$ & Item matter Valid \\
8 & $.421^{* *}$ & $>0,300$ & Item matter Valid \\
9 & $.395^{* *}$ & $>0,300$ & Item matter Valid \\
10 & 1 & $>0,300$ & Item matter Valid \\
\hline
\end{tabular}




\begin{tabular}{llll}
\hline 11 & $.388^{* *}$ & $>0,300$ & Item matter Valid \\
12 & $.479^{* *}$ & $>0,300$ & tem matter Valid \\
13 & $.606^{* *}$ & $>0,300$ & Item matter Valid \\
14 & $.367^{* *}$ & $>0,300$ & Item matter Valid \\
15 & $.353^{* *}$ & $>0,300$ & Item matter Valid \\
\hline
\end{tabular}

Source: data analysis.

\subsubsection{Test Reliability}

Reliability test is intended to determine the consistency of measuring instruments in use , or in other words the instruments have consistent results when used repeatedly at different times (Nata Wirawan, 2002). Reliability test results as the table below:

Table 5. Reliability testing results

\begin{tabular}{lcc}
\hline \multicolumn{1}{c}{ Variable } & Minimum limit & information \\
\hline Venture capital (X1) & 0.700 & \\
JTK(X2) & 0.700 & \\
Working hours (X3) & 0.700 & \\
experience (X4) & 0.700 & \\
Tehcnology (X5) & 0.700 & \\
Strategy market (X6) & 0.700 & \\
\hline
\end{tabular}

Source: data analysis.

\subsubsection{Classic Assumption Test}

\subsubsection{Normality Test Data}

Normality test can be done in two ways . Namely the "Normal P - P Plot" and "Table Kolmogorov Smirnov". The most commonly used is Normal P-P.

From the analysis of the curve can be seen that the data is spread around the diagram and follow the regression model so that it can be concluded that the processed data is the data so that the normal distribution normality test is met .

\subsubsection{Test Multicolinearity}

This test aims to test whether the regression model found a correlation between independent variables (independent). A good regression model should not happen correlation between the independent variables. If the independent variables are correlated then these variables are not orthogonal (Ghozali, 2006) For analysis with SPSS output we see the results in the table "Coefficients". As in the following table:

Table 6. Test multicolinearity

\begin{tabular}{llll}
\hline Variable & VIF amount & value Regression & Interpretation \\
\hline Sales volume ( Y ) & - & VIF $<10$, & Variable Dependent \\
Venture capital (X1) & 1.653 & VIF $<10$, & not happen multikolinearitas \\
The number of workers(X2) & 1.108 & VIF $<10$, & not happen multikolinearitas \\
Working hours (X3) & 1.769 & VIF $<10$, & not happen multikolinearitas \\
Business experience (X4) & 1.311 & VIF $<10$, & not happen multikolinearitas \\
Technology and innovation in production (X5) & 1.243 & VIF $<10$, & not happen multikolinearitas \\
Marketing strategy (X6) & 1.214 & VIF $<10$, & not happen multikolinearitas \\
\hline
\end{tabular}

Source: Results of the data analysis.

From the results of the output data obtained that the value of all VIF $<10$ This means that not happen multicoloniarity. And concluded that the test multicoloniarity met. 


\subsubsection{Test Heteroskidastity}

This test is used to see if the confounding variables have the same variant or not (Ghozali, 2006). From the analysis it can be seen that does not happen heteroskedastisity because no clear pattern as well as the points spread above and below the number 0 on the $\mathrm{Y}$ axis so that it can be said heteroscedasticity test is met test Autocorrelation.

Autocorrelation test is a test of the assumptions in the regression where the dependent variable is not correlated with itself. To analyze them using SPSS output before we look at the table "Model Summary". such as the following:

Table 7. Test autocorrelation

\begin{tabular}{lcccc} 
& Modle & Amount Durbin-Watson & number Durbin-Watson $(\alpha)$ & Interpretation \\
\cline { 2 - 5 } & Regression & 1.252 & -2 to +2 & no autocorrelation \\
\cline { 2 - 4 } Source: Analysis of data. & & &
\end{tabular}

From the above table values obtained Durbin - Watson (DW count) of 1,252. Based on predetermined criteria DW count is between -2 and 2 , ie $-2 \leq 2 \leq 2$ then this means no autocorrelation. So the conclusion is the autocorrelation test is met. Based on the results of various kinds of tests can be concluded that the requirements have been met all the classical assumption that the data analysis using multiple regression equation to do.

\subsubsection{Multiple Linear Regression Analysis}

Multiple linear regression analysis was used to determine whether there is influence of the independent variable on the dependent variable.

Table 8. Regression analysis

\begin{tabular}{|c|c|c|}
\hline Variable & value Regression & Interpretation \\
\hline Sales volume ( Y) & 14,563 & Positive influence on the variable $\mathrm{x}$ \\
\hline Venture capital ( $X_{1)}$ & -0.033 & Positive influence on the variable $y$ \\
\hline The number of workers $\left(X_{2}\right)$ & -0.371 & Positive influence on the variable $y$ \\
\hline Working hours $\left(\mathrm{X}_{3}\right)$ & -.0 .307 & Positive influence on the variable $y$ \\
\hline Business eksperience $\left(\mathrm{X}_{4}\right)$ & 0.061 & Positive influence on the variable $y$ \\
\hline Tehcnology and innovation in production $\left(\mathrm{X}_{5}\right)$ & $0 . .209$ & Positive influence on the variable $y$ \\
\hline Marketing strategy $\left(\mathrm{X}_{6}\right)$ & 0.146 & Positive influence on the variable y \\
\hline
\end{tabular}

Source : Analysis of data.

Based on the above table can be obtained regression formula as follows :

$$
Y=14.563-0.033 X_{1}-0.371 X_{2}-0.307 X_{3}+0.061 X_{4}+0.209 X_{5}+0.146 X_{6}+\varepsilon
$$

\subsection{Interpretation of the Results of the Regression Analysis above Are as Follows}

1). The constant, this means that if all variables have a value of zero (0) then the value of the dependent variable (sales volume) amounted to 14563.

2). Venture Capital (X1) to Sales Volume (Y), the coefficient value for the variable X1 Business Capital amounted to - 0.033. This shows that the Venture Capital have a relationship in the opposite direction (negative) with a Sales Volume or imply that any increase in Venture Capital one unit then the variable Sales Volume (Y) will be decreased by 0033, assuming that the independent variables other than the regression model is permanent.

3). Number of Workers (X2) on the Sales Volume (Y), Coefficient of Total Workforce for X2 of - 0.371. This shows that the amount of Labor have a relationship in the opposite direction to the sales volume or imply that any increase in Total Labor one unit then the variable Sales Volume (Y) will be decreased by 0371, assuming that the independent variables other than the regression model is fixed,

4). Hours of Work (X3) on Sales Volume (Y), Working Hours coefficient value for the variable X3 for - 0307. This indicates that the Working Hours have a relationship in the opposite direction to the sales volume or implies that each increase of one unit of the Working Hours Sales Volume variable (Y) will be decreased by 0307 assuming that 
the other independent variables from the regression model is fixed.

5). Experience (X4) of the Sales Volume (Y), the coefficient value for the variable $X 4$ experience of 0061 . This implies that every increase of one's experience, the unit sales volume variable $(Y)$ will increase by 0061 under the assumption that the other independent variables from the regression model is fixed.

6). Technology and Innovation Prod. (X5) on Sales Volume (Y), coefficient of Technology and Innovation Prod. for variable X5 for 0209. This implies that any increase in Technology and Innovation Prod. one unit of the variable Sales Volume (Y) will increase by 0209 under the assumption that the other independent variables from the regression model is fixed.

7). Marketing Strategy (X6) of the Sales Volume (Y).

The coefficient value for the variable X6 Marketing Strategies for 0146. This implies that each increase of one unit of the Marketing Strategy Sales Volume variable (Y) will increase by 0146 under the assumption that the other independent variables from the regression model is in line with research in Imam Syarif Hidayat (2008).

\subsection{Hypothesis Testing}

\subsubsection{T Test}

Hypothesis testing is done by using $t$ tests were used to determine whether the independent variables partially real effect or not on the dependent variable. The degree of significance used was 0.05 . If the value is significantly smaller than the degree of confidence then we accept the alternative hypothesis, which states that a partially independent variables affect the dependent variable. T test analysis is also seen from the table "Coefficient". $\mathrm{T}$ test analysis is also seen from the table "Coefficient".

Table 9. Coefficient

\begin{tabular}{cccc}
\hline Variable & value significant & Extentf significant $(\alpha)$ & Interpretation \\
\hline Sales volume $(\mathrm{Y})$ & 0.000 & 0.05 & -- \\
Venture capital $\left(\mathrm{X}_{1}\right)$ & 0.786 & 0.05 & Var. $\left(\mathrm{X}_{1}\right)$ ) is not significant to the variable $\mathrm{y}$ \\
Total manpower $\left(\mathrm{X}_{2}\right)$ & 0.047 & 0.05 & Var. $\left(\mathrm{X}_{2}\right)$ significant to the variable $\mathrm{y}$ \\
Working hours $\left(\mathrm{X}_{3}\right)$ & 0,196 & .0 .05 & Var. $\left(\mathrm{X}_{3}\right)$ is not significant to the variable y \\
Trying experience $\left(\mathrm{X}_{4}\right)$ & 0.692 & 0.05 & Var. $\left(\mathrm{X}_{4}\right)$ is not significant to the variable y \\
Technology and innovation in production $\left(\mathrm{X}_{5}\right)$ & 0,000 & 0.05 & Var. $\left(\mathrm{X}_{5}\right)$ significant to the variable y \\
Marketing strategy $\left(\mathrm{X}_{6}\right)$ & 0.041 & 0.05 & Var. $\left(\mathrm{X}_{6}\right)$ significant to the variable y \\
\hline
\end{tabular}

Source: Analysis of data.

Based on $\mathrm{t}$ test results can be said that:

1). Business Capital (X1) to Sales Volume (Y)

H0: Venture Capital (X1) no significant impact on sales volume (Y);

H1: Venture Capital (X1) significantly affects Sales Volume (Y).

0786 sig value is greater than the degree of significance $(\alpha) 0.05$ then the decision could be made that $\mathrm{H} 0$ failed rejected. It can be concluded that the Venture Capital (X1) no significant impact on sales volume (Y). it is not in line with the research Fenny Lianti (2011), Chuthamas Chittithaworn; 2011 and Javed Mahmood Jasra (2011), Taufiq (2006).

2). Number of Workers (X2) on the Sales Volume (Y)

H0: Number of Workers (X2) no significant impact on sales volume (Y);

H1: Number of Workers (X2) significantly affects Sales Volume (Y).

0047 sig value is smaller than a significant degree $(\alpha) 0.05$ then the decision could be made that $\mathrm{H} 0$ is rejected. It can be concluded that the amount of Labor (X2) significantly affects Sales Volume (Y).It is step by Deepak K. Datta and Grisna Anggadwita, Qaanita Yuuha Mustafid (2014).

3). Working Hours (X3) on Sales Volume (Y)

H0: Hours of Work (X3) no significant impact on sales volume (Y);

H1: Working Hours (X3) significantly affects Sales Volume (Y). 
0196 sig value is greater than the degree of significance $(\alpha) 0.05$ then the decision could be made that $\mathrm{H} 0$ failed rejected. It can be concluded that the Hours of Work (X3) no significant impact on sales volume (Y). it is contrary to the study of Berchman Prana Sasmita et al.

4). Experience (X4) of the Sales Volume (Y)

H0: Experience (X4) no significant impact on sales volume (Y);

H1: Experience (X4) significantly affects Sales Volume (Y).

0682 sig value is greater than the degree of significance $(\alpha) 0.05$ then the decision could be made that H0 failed rejected. It can be concluded that the experience (X4) no significant impact on sales volume (Y). this is in line with research Kladiola Gjini and not sejaan with research Firdouse Rahman Khan (2014)

5). Technology and Innovation Production. (X5) on Sales Volume (Y)

H0: Production Technology and Innovation. (X5) no significant impact on sales volume (Y);

H1: Technology and Production Innovation. (X5) significantly affects Sales Volume (Y), 0.000 sig value is smaller than a significant degree $(\alpha) 0.05$ then the decision could be made that $\mathrm{H} 0$ is rejected. It can be concluded that the Technology and Innovation Production. (X5) significantly affects Sales Volume (Y). This is in line with Chuthamas Chittithaworn (2011) and Fat Sukarno (2009), and Bramuel Kitisha Kedogo (2013), Dimitrios Buhalis, Hilary Main; (1998), and Grisna Anggadwita,, Qaanita Yuuha Mustafid (2014).

6). Marketing Strategy (X6) of the Sales Volume (Y)

H0: Marketing (X6) no significant impact on sales volume (Y);

H1: Marketing (X6) significantly affects Sales Volume (Y).

$0041 \mathrm{sig}$ value is smaller than a significant degree $(\alpha) 0.05$ then the decision could be made that $\mathrm{H} 0$ is rejected. It can be concluded that the Marketing Strategy (X6) significantly affects Sales Volume (Y). This is in line with research Chuthamas Chittithaworn (2011), Mohammed S, Zahurul Alam, Md. Ifttekhar Arif (2013) and not in line with the research Veronica Sri Lestari, (2005).

\subsubsection{Test $\mathrm{F}$}

F test used to determine whether the independent variables simultaneously significant effect on the dependent variable. Confidence level used was 0.05 . If the $F$ value calculation result is greater than the value $F$ according to the table then the alternative hypothesis, which states that all independent variables simultaneously significant effect on the dependent variable.

Tabel 11. Uji F

\begin{tabular}{lccc}
\hline Modle & value $\mathrm{F}$ & degree of confidence $(\alpha)$ & Interpertationi \\
\hline Regression & 9.558 & 0.05 & Variable X together influential variable y \\
\hline
\end{tabular}

Source: Analysis of data.

Based on the above results, the hypothesis proposed reads:

H0: Venture Capital (X1), Total Labor (X2), Hours of Work (X3), Experience (X4), Technology and Innovation Prod. (X5), Marketing Strategy (X6) no significant impact on sales volume (Y).

H1: Venture Capital (X1), Total Labor (X2), Hours of Work (X3), Experience (X4), Technology and Innovation Prod. (X5), Marketing Strategy (X6) significantly affects Sales Volume (Y), From the table values obtained Fhitung 9558 with a probability value $(\mathrm{sig})=0.000$. sig. smaller than the probability value 0.05 or value $0.000<$ 0.05; then H0, H1 means together (simultaneously) Venture Capital (X1), Total Labor (X2), Hours of Work (X3), Experience (X4), Technology and Innovation Prod. (X5), Marketing Strategy (X6) significantly affects Sales Volume (Y).

The coefficient of determination $\left(\mathrm{R}^{2}\right)$.

The coefficient of determination used to determine how much the relationship of multiple variables within the meaning clearer. The coefficient of determination will explain how big a change or variation of a variable can be explained by changes or variations in other variables in the sense that the ability to contribute to the independent variable fixed variable in units of percentage. This coefficient values between 0 and 1 , if the result is closer to the 
number 0 means the ability of the independent variables in explaining the variation of variables is very limited. But if the result of close to 1 means that the independent variables provide almost all the information needed to predict the variation of the dependent variable.

Table 12. Koefisien determinasi $\left(\mathrm{R}^{2}\right)$

\begin{tabular}{cccccc}
\hline Modle & nilai $\mathrm{R}$ & nilai R Square & & \multicolumn{1}{c}{ Interpretation } \\
\hline Regression & $.616^{\mathrm{a}}$ & .379 & Variabel & $\mathrm{X}$ & weak effect was variable y \\
\hline
\end{tabular}

Sumber: Hasil Analysis data.

Based on the table above it can be concluded that the Venture Capital (X1), Total Labor (X2), Hours of Work (X3), Experience (X4), Technology and Innovation Prod. (X5), Marketing Strategy (X6) effect amounted to $37.9 \%$ of the sales volume (Y), in other words the effect is weak, whereas $65.1 \%$ influenced by other variables not studied. Because adjusted R Square tend to approach a value of 0 , it can be concluded capability independent variables in explaining the variation of variables is very limited.

\section{Conclusions and Recommendations}

\subsection{Conclusion}

1). Answering the research problems which reads: venture capital, workforce, and business experience, technology and production innovation, marketing strategies increased the sales volume of SMEs in Surabaya, then based on the results of data analysis can be concluded that the Venture Capital (X1), Total Power Work (X2), Hours of Work (X3), experience (X4), Technology and Innovation Prod. (X5), Marketing Strategy (X6) effect amounted to 37.9\% of the sales volume (Y), whereas $65.1 \%$ influenced by other variables not studied. Because adjusted R Square of $37.9 \%$ likely to approach a value of 0 , it can be concluded that the ability of the independent variables influence was the dependent variable. These results are consistent research conducted by Amirina, Nur Annisa (2011), Rizki Herdiansyah (2013) and Lew Perren, (1999). These results are consistent research conducted by Werner H. Hoffmann, Roman Schlosser (2001), but not sejaan by Dimitrios Buhalis, Hilary Main, (1998).

2). Among the factors working capital, number of employees, hours of work and business experience, production technology, product innovation, marketing strategy where the dominant influence on the increase of sales volume of SMEs in Surabaya? .Based on Data analysis Coefficient of Technology and Innovation Prod. for variable X5 for 0209, it can be said that the Technology and Innovation Production dominant influence on the sales volume. These results are consistent with research conducted by Made Saryawan1, Sudirman and I Wayan G W Murjana Yasa.

\subsection{Suggestion}

Based on the results of data analysis studies were obtained in the field it can be be given advice follows:

1) To promote SMEs in the city of Surabaya needed technology and product innovation, so that SMEs can produce products that have a high innovation touch of art production so it can be preferred by consumers, which in turn enables high sales volume.

2) Necessary for innovation in product marketing strategies in order to have competitiveness against products from other businesses.

3) Need for assistance on SMEs to be able to use strategies in marketing their production through the existing media, especially the accessible broadly in the hope enables high sales voleume.

\section{Limitations of the Study}

Samples are limited in number to the research needs to be expanded sample selanjtnya.

The research variables can be added to make it more complete results.

\section{References}

Berchman, P. S., \& Gunawan, S. D. T. R. (n. d.). Effect of Capital and Long Work Hours Against Street Vendors Income Level, Education Economics IPS FKIP Unila Bandar Lampung.

Bracker, J., \& Pearson, J. (1986). Planning and financial performance of small, mature firms. Strategic Management Journal, 7(6), 503-522. http://dx.doi.org/10.1002/smj.4250070603

Bridge, S., O’Neill, K., \& Cromie, S. (2003). Understanding Enterprise, Entrepreneurship and Small Business (2nd ed.). New York. Palgrave Macmillan. 
Budi, H. (n. d.). Encourage competitiveness in the Information Age and Globalization utilization of intellectual capital and a base sabagai Information Technology Innovation in Companies. University Gunadarma Jakarta, Retrieved from http:/bhermana.staff gunadarma.ac.id

Choirul, A. (2012). Micro: Contributions SMEs Reaches 33\% to GDP dissemination in Indonesia The International Journal of Entrepreneurship and Innovation, 4(4), 251-263.

Chuthamas, C., Thiyada, K., \& Dayang, H. M. (2011). Factors Affecting Business Success of Small \& Medium Enterprises (SMEs) in Thailand. Asian Journal of Social Science, 7(5).

Dimitrios, B., \& Hilary, M. (1998). Information technology in peripheral small and medium hospitality enterprises: Strategic analysis and critical factors. International Journal of Contemporary Hospitality Management, 10(5), 198-202. http://dx.doi.org/10.1108/09596119810227811

Fenny, L. (2011). Working Capital Needs Analysis And Acquisition Of Sales Volume Net Income In Automotive Industry Corporation And Its components Listed on the Stock Exchange. Library UNIKOM.

Firdouse, R. K. (2014). Socio-Economic Factors Influencing Entrepreneurship Development: An Empirical Study Across the Small and Medium Enterprises of Chennai. International Journal of Students Research in Technology \& Management, 2(3), 89-94.

Gadenne, D. (1998). Critical success factors for small business: An inter-industry comparison. International Small Business Journal, 17(1), 36-56. http://dx.doi.org/10.1177/0266242698171002

Gendut, S. (2009). Improving Marketing Performance Role of SMEs Through Environmental, Product Innovation and Creativity in Marketing Strategy.

Ghosh, B., \& Kwan, W. (1996). An analysis of key success factors of SMEs: A comparative study of Singapore/Malaysia and Australia/New Zealand. In The 41st ICSB World Conference Proceedings I, 215-252. Stockholm, Sweden, June 16-19.

Ghozali, I. (2006). Applications Multivariate Analysis with SPSS Program. Semarang: BP UNDIP.

Grisna, A., \& Qaanita, Y. M. (2013). Identification of Factors Influencing the Performance of Small Medium Enterprises (SME). Procedia - Social and Behavioral Sciences, 115, 415-423.

Javed, M. J., Muhammad, A. K., Ahmed, I. H., Rana, A. Ur R., \& Rauf, I. A. (2011). Determinants Of Business Success Of Small And Medium Enterprises. International Journal of Business and Social Science, 2(20), November 2011.

Kauranen, I. (1996). The start-up characteristics of a new entrepreneurial firm as determinants of the future success of the firms in the short term and in the long term. Journal of Enterprising Culture, 4(4), 363-383. http://dx.doi.org/10.1142/S0218495896000216

Kladiola, G. (n. d.). Small And Medium Sized Entreprises; Growth Factors In Albania. University 'Aleksander Xhuvani', Albania.

Kristiansen, S. (2002). Competition and Knowledge in Javanese Rural Business. Singapore Journal of Tropical Geography, 23(1), 52-70. http://dx.doi.org/10.1111/1467-9493.00118

Kristiansen, S. (2003). Linkages and Rural Non-Farm Employment Creation: Changing Challenges and Policies in Indonesia. Rome.

Kristiansen, S., \& Indarti, N. (2004). Entrepreneurial Intention among Indonesian and Norwegian Students. Journal of Enterprising Culture, 12(1). http://dx.doi.org/10.1142/S021849580400004X

Kristiansen, S., Furuholt, B., \& Wahid, F. (2003). Internet cafe entrepreneurs: Pioneers in information.

Lew, P. (1999). Factors in the growth of micro - enterprises (Part 1): Developing a framework. Journal of Small Business and Enterprise Development, 6(4), 366-385. http://dx.doi.org/10.1108/EUM0000000006691

Malhotra, M., Chen, Y., Criscuolo, A., Fan, Q., Hamel, I., \& Savchenko, Y. (2006). Expanding access to finance: Good practices and policies for micro, small, and medium enterprises.

McMahon, R. G. P. (2001). Growth and performance of manufacturing SMEs: The influence of financial management characteristics. International Small Business Journal, 19(3), 10-28. http://dx.doi.org/10.1177/0266242601193001

Mohammed, S., Zahurul, A., \& Md. Ifttekhar, A. (2013). Success Factors of Entrepreneurs of Small and Medium Sized Enterprises: Evidence from Bangladesh. Business and Economic Research, 3(2), 38-52. 
http://dx.doi.org/10.5296/ber.v3i2.4127

Nata, W. (2002). Statistics 2 (statistical inference) (2nd ed.). Denpasar: Keraras Emas.

Nunuy, N. A. (2009). Strengthening SME Indonesia face the global financial crisis. Working Paper In Accounting and Finance, October (Department of Accounting, Padjadjaran University).

Nurul, I., \& Marja, L. (2005). A Study of Factors Affecting Business Success among SMEs: Empirical Evidences from Indonesia.

OECD (Organisation for Economic Co-operation and Development). (2004). Promoting Entrepreneurship and Innovative SMEs in a Global Economy: Towards a More Responsible and Inclusive Globalisation. Second OECD Conference of Ministers Responsible for Small and Medium-Sized Enterprises (SMEs), Executive Summary of the Background Papers, Paris, France: OECD.

Pelham, A. (2000). Market orientation and other potential influences on performance in small and medium-sized manufacturing firms. Journal of Small Business Management, 38(1), 48-67.

Sugiyono. (2007). Business Research Methods. Bandung: CV.ALFABATA.

Swierczek, F. W., \& Ha, T. T. (2003). Entrepreneurial orientation, uncertainty avoidance and firm performance: An analysis of Thai and Vietnamese SMEs. International Journal of Entrepreneurship and Innovation, 4(1), 46-58. http://dx.doi.org/10.5367/000000003101299393

Syarif, I. H. (2008). Analysis of Factors Affecting Sales Volume Processed Products Chips "French Fried". Jurna Social Economics of Agriculture, 2(1).

Taufiq. (2006). Use of Credit Funds Against Sme Business Improvement (study on SMEs Sandals and Shoes Wedoro Desa Waru Sidoarjo). Journal of Economic Sciences, 6(2), 125-136.

Veronica, S. L. (2005). Analysis of Some Factors Affecting Sales Volume of Cuisine Chicken (Case study Eating Lesehan father of Dani). Universitas Hasanaudin Makasar.

Werner, H., \& Hoffmann, R. S. (2001). Success Factors of Strategic Alliances in Small and Medium-sized Enterprises-An Empirical Survey. Long Range Planning, 34(3), 357-381. http://dx.doi.org/10.1016/S0024-6301(01)00041-3

Westhead, P. (1995). Survival and employment growth contrasts between types of owner-managed high technology firms. Entrepreneurship Theory \& Practice, 20(1), 5-28.

Wijewardena, H., \& Cooray, S. (1996). Factors contributing to the growth of small manufacturing firms:perceptions on Japanese owner/managers. Journal of Enterprising Culture, 4(4), 351-361. http://dx.doi.org/10.1142/S0218495896000204

Wiklund, J., \& Shepherd, D. (2004). Entrepreneurial Orientation and Small Business Performance: A Configurational Approach. Journal of Business Venturing, 20(1), 71-91. http://dx.doi.org/10.1016/j.jbusvent.2004.01.001

William, G., James, M., \& Susan, M. (2005). Fundamentals of Business: Starting a Small Business. New York: McGraw-Hill/Irwin.

Yusuf, A. (1995). Critical success factors for small business: Perceptions of South Pacific entrepreneurs. Journal of Small Business Management, 33(2), 68-73.

\section{Copyrights}

Copyright for this article is retained by the author(s), with first publication rights granted to the journal.

This is an open-access article distributed under the terms and conditions of the Creative Commons Attribution license (http://creativecommons.org/licenses/by/3.0/). 